\title{
Removal of Reactive Dye from Textile Mill Wastewater by Leading Electro-Coagulation Process Using Aluminum as a Sacrificial Anode
}

\author{
Mervat A. Sadik \\ October High Institute for Engineering \& Technology, Giza, Egypt \\ Email: sadikmervat@yahoo.com
}

How to cite this paper: Sadik, M.A. (2019) Removal of Reactive Dye from Textile Mill Wastewater by Leading Electro-Coagulation Process Using Aluminum as a Sacrificial Anode. Advances in Chemical Engineering and Science, 9, 182-193.

https://doi.org/10.4236/aces.2019.92014

Received: February 25, 2019

Accepted: April 19, 2019

Published: April 22, 2019

Copyright $\odot 2019$ by author(s) and Scientific Research Publishing Inc. This work is licensed under the Creative Commons Attribution International License (CC BY 4.0).

http://creativecommons.org/licenses/by/4.0/

(c) (i) Open Access

\begin{abstract}
This work presents the highest color removal efficiency for Textile wastewater by Electrocoagulation (EC) process using Aluminum as a sacrificial anode which is presently used for the purification of many types of water and wastewater. The effecting parameters such as applied electrical current, electrolysis time and initial $\mathrm{pH}$ were studied to achieve higher removals. In this process, sample was taken from real effluent of reactive dyes fabric. The performance of Electrocoagulation process was carried out in batch reactor at regular interval of 20 minutes. Obtained results indicated the most effective color removal efficiency was achieved at $0.75 \mathrm{~A}$ of applied electrical Current. They were $(97.5 \%-98.1 \%)$, at electrolysis time of 120 minutes, $\mathrm{pH} 10, \mathrm{pH} 7$ respectively and COD removal efficiency was $(54 \%-65 \%)$ at $0.75 \mathrm{~A}, 0.9 \mathrm{~A}$ respectively. In this work, the initial $\mathrm{pH}$ did not strongly affect the removal efficiencies significantly over a wide range. Therefore, adjustment of initial $\mathrm{pH}$ before treatment was not required in this practical application. The power consumption was found to be $6 \mathrm{kWh} / \mathrm{m}^{3}$. To determine COD removal rate dependency to electrical current, a kinetic study was carried out and data were in good covenant with the first order kinetic model.
\end{abstract}

\section{Keywords}

Electrocoagulation/Flotation, Textile Wastewater, Decolorization

\section{Introduction}

The Textile industry is an important sector of our economy. One of the main industries consumes large quantities of water and produces large volumes of wastewater. Furthermore, with this point of view, many industries throw its wastewater in the environment. Therefore, the major tasks are providing clean 
water to all living organism. There is an urgent need to innovate more effective and inexpensive technique for treatment of wastewater. One of the most serious causes of disease and serious environmental problems is dye wastewater in general that consists of a number of contaminants, including acids, bases, dissolved and suspended solids, toxic and non-biodegradable compounds, which are conspicuous even at low concentrations and need to be removed before the wastewater can be discharged to environment [1] [2]. Electrocoagulation (EC) is an attractive technique for the treatment of effluent in which there is an in-situ generation of coagulant by the dissolution of sacrificial anode. The application of current leads to the generation of hydroxide ions at the anode and hydrogen gas at the cathode. The generation of the hydroxide ions leads to the formation of flocs, which settles the pollutant and can be easily removed by sedimentation. There is formation of gas bubbles, which help the lighter pollutants to be removed by flotation [3]. Experiments done in Textile wastewater contained a significant amount of bio dye compounds including Reactive Black 5 (RB5) as an Azo dye which causes serious damage to the environment and aquatic life in receiving water resources by [4]. An excessive intake of fluoride causes severe dental or skeletal fluorosis. Therefore, [5] revealed a maximum hardness removal by electrocoagulation process and applied the influence of fluoride ions on hardness removal. Another attempt [6] removed COD from Textile Mill Wastewater by Electro-Coagulation Process using SS/Al as Composite Hydrogel and compared (SS-Ti) and Aluminium-Titanium (Al-Ti) for removal of COD from Textile Mill. As well, [7] treated tannery wastewater sample to remove or reduce the pollutants load by using electrocoagulation technique using an electrode of aluminum nanoparticles. [8] treated wastewater from industrial pulp and paper recycling using electrocoagulation. Aluminum (Al) and Iron (Fe) electrodes were used as the electrochemical cell set up. On the other hand, [9] treated the surface water by Electrocoagulation-Electro flotation process in internal loop airlift reactor and evaluated of the performance of the treatment by measuring the electrolysis time, the effect of the initial electrical conductivity on the reduction of the turbidity and the electrical energy consumption. [10] selected Anodes ( $\mathrm{Al}$ and $\mathrm{Fe}$ ) and cathode (graphite and $\mathrm{Ti} / \mathrm{RuO}_{2}$ ) materials for purification of the acid whey using electrocoagulation technique. [11] selected a model dye as Remazol Black B and treated by Electrocoagulation Process Coupled with Bentonite as an Aid Coagulant and Natural Adsorbent and results showed that it's effective method for dye removal from colored wastewater. [12] investigated that another type of waste water causes of disease and serious environmental problems is abattoir wastewater by electrocoagulation (EC) process using iron electrodes and its result. Results showed that EC technique using Fe-Fe electrodes is effective in abattoir wastewater treatment.

Therefore, instead of Conventional treatment technologies, such as chemical coagulation, biological methods and advanced oxidation processes, such as ozonation and $\mathrm{UV} / \mathrm{H}_{2} \mathrm{O}_{2}$ that cannot purify dying effluent. [13] [14] all of previous methods have some limitations and problems. Biological treatment by activated 
sludge offers high efficiencies in COD removal, but does not completely eliminate the color of the wastewater and frequently operational problems such as bulking appear. Chemical oxidation by ozone, or a combination of UV-radiation and ozone and $\mathrm{H}_{2} \mathrm{O}_{2}$, has great interest, but the costs are still very high due to the high doses required. Coagulation-flocculation process has been found to be cost effective, easy to operate and energy saving treatment alternatives, but the coagulation process does not work well for soluble dyes. we can used promising electrocoagulation treatment technology method that that used electrons only employed agents in ECF being responsible for facilitating wastewater treatment

[15] Mechanism of the electro coagulation process By using aluminum electrodes are:

$$
\begin{gathered}
\mathrm{Al}(\mathrm{s}) \rightarrow \mathrm{Al}^{+3} \mathrm{aq}+3 \mathrm{e}-(\text { anode }) \\
3 \mathrm{H}_{2} \mathrm{O}+3 \mathrm{e}^{-} \rightarrow 3 / 4 \mathrm{H}_{2} \mathrm{~g}+3 \mathrm{OH}^{-} \text {aq }(\text { cathode })
\end{gathered}
$$

$\mathrm{Al}^{3+}$ and $\mathrm{OH}^{-}$ions generated by electrode reactions (1) and (2) react to form various monomeric species, which finally transform into $\mathrm{Al}(\mathrm{OH})_{3}(\mathrm{~s})$ according to complex precipitation kinetics:

$$
\mathrm{Al}^{+3} \mathrm{aq}+3 \mathrm{OH}^{-} \rightarrow \text { aq } \mathrm{Al}(\mathrm{OH})_{3}
$$

Freshly formed amorphous $\mathrm{Al}(\mathrm{OH})_{3}(\mathrm{~s})$ "sweep flocs" exhibit large surface areas which are beneficial for a rapid adsorption of soluble organic compounds and for trapping colloidal particles. Finally, these flocs are removed easily from aqueous [16] [17] medium by sedimentation or by flotation cathode

The main purpose of this work is to study the electro coagulation process efficiency for treatment real waste water from a local factory which used reactive dyes and determined of the important variables such as electrical current, initial $\mathrm{pH}$ on removal dye (Figure 1).

\section{Material and Method}

\subsection{Analytical Measurements}

The Textile wastewater used in this study is obtained from a tank containing a mixture of exhaust dyeing solutions at a textile factory and was stored in deep freezer with preservatives. The composition of the wastewater is shown in Table 1. COD, total suspended solids (TSS), total organic carbon (TOC) and turbidity were carried out according to the Standard Methods for Examination of Water and Wastewater [19]. The COD samples were analyzed using a Shimadzu Model UV-160 double beam spectrophotometer. The $\mathrm{pH}$ was measured with a $\mathrm{pH} \mathrm{Me}-$ tera (Lovibondp). Conductivity was determined A Jenway Conductivity Meter (Model 4200) was employed to determine the conductivity, The $\mathrm{pH}$ and conductivity were adjusted to a desirable value using $\mathrm{NaOH}$, and $\mathrm{NaCl}$ (Merck), respectively The various characteristics of Textile effluent are shown in Table 1.

$$
E,(\%)=\left(C_{i}-C_{f}\right) / C_{i}
$$




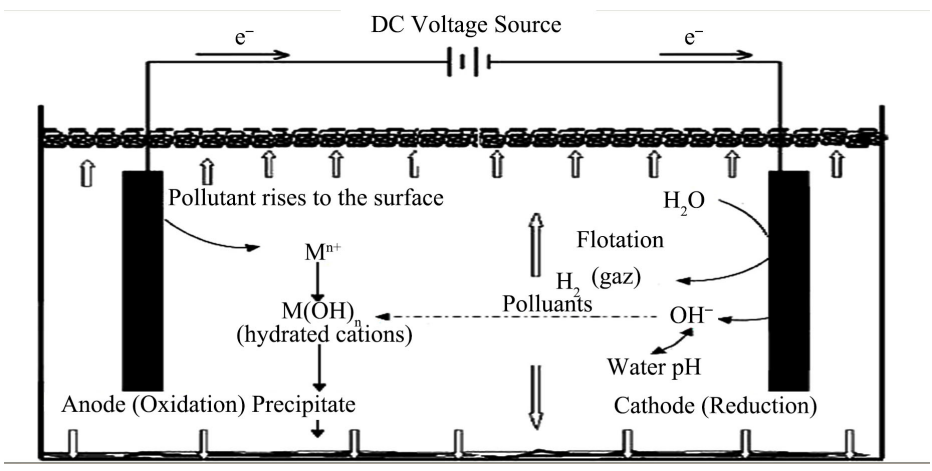

Figure 1. Mechanism of electrocoagulation adopted from [18].

Table 1. Characteristics of wastewater from textile mill.

\begin{tabular}{ccc}
\hline Characteristics & Unit & $\begin{array}{c}\text { Raw } \\
\text { wastewater }\end{array}$ \\
\hline $\mathrm{pH}$ & - & 10 \\
Color & Indigo blue & 1.25 \\
Conductivity & $\mathrm{mS} / \mathrm{cm}$ & 75,800 \\
Alkalinity & $\mathrm{mg} / \mathrm{L}$ & 2870 \\
Total dissolved solid & $\mathrm{mg} / \mathrm{L}$ & 41,100 \\
Suspended solid & $\mathrm{mg} / \mathrm{L}$ & 760 \\
Total solids & $\mathrm{mg} / \mathrm{L}$ & 41,760 \\
BOD & $\mathrm{mg} / \mathrm{L}$ & 450 \\
COD & $\mathrm{mg} / \mathrm{L}$ & 1100 \\
Chlorides & $\mathrm{mg} / \mathrm{L}$ & 19,752 \\
Nitrate & $\mathrm{mg} / \mathrm{L}$ & 1.8 \\
Sulphate & $\mathrm{mg} / \mathrm{L}$ & 4700 \\
Phosphate & $\mathrm{mg} / \mathrm{L}$ & 6.9 \\
\hline
\end{tabular}

where $C_{i}$ is the initial dye concentration $(\mathrm{mg} / \mathrm{L})$ and $C_{f}$ is the final dye concentration $(\mathrm{mg} / \mathrm{L})$. In this study, each treatment was repeated twice and the absorbance measurement of each sample was repeated three times and all of the data in the Figures.

\subsection{Experimental Set up}

Electrolysis cell consists of a power supply system and a magnetic stirrer unit. The electrolysis cell made of borosil glass beaker with an effective volume of $1 \mathrm{~L}$ and Bipolar electrode in serial connections (BP-S). The Aluminum cathode and Aluminum anode consist of pieces of size $10 \mathrm{~cm} \times 5 \mathrm{~cm} \times 1 \mathrm{~mm}$ separated by a space of $1 \mathrm{~cm}$ and dipped in the wastewater. Experiments in a bipolar batch reactor (Figure 2), with four aluminum electrode connected the electrodes are connected to the positive and negative terminals of the DC power supply (Range $30 \mathrm{~V} / 3 \mathrm{~A}$ ) and no electrical connection between the inner electrodes, A magnetic stirrer was used to provide mixing of the solution as shown in Figure 2. In this 
study, an effect of electrical current, $\mathrm{pH}$ and Electrolysis time is studied. All the runs were performed at constant temperature of $25^{\circ} \mathrm{C}$. In each run, $500 \mathrm{~cm}^{3}$ of the wastewater solutions was placed into the electrolytic cell. The electrical current was adjusted to a desired value and the coagulation was started. At the end of electrocoagulation, the solution was filtered and the filtrate was centrifugated at $2000 \mathrm{rpm}$, and then was analyzed. Before each run, electrodes were washed with acetone to remove surface grease, and the impurities on the aluminum electrodes surfaces were removed by dipping for $5 \mathrm{~min}$. Electrical energy consumption $(\mathrm{Ec})$ in $\mathrm{KWh} / \mathrm{m}^{3}$ dye wastewater was estimated using equation reported by [20] described below:

$$
\operatorname{Ec}\left(\mathrm{kWh} / \mathrm{m}^{3}\right)=\frac{V \times I \times t}{\mathrm{~m}^{3} \text { wastewater } \times 1000}
$$

where $(V)$ is the voltage in Volt, $(I)$ is the electrical current in Ampere, $(t)$ is the reaction time in hour and $\left(\mathrm{m}^{3}\right)$ is the volume of the wastewater (reactor) in cubic meter. Bipolar electrode in serial connections (BP-S): In this connection mode, the outer electrodes are connected to the power supply and there is the no electrical connection between the inner electrodes. [21] reported that MP-P mode is the most cost effective for aluminum electrodes.

\section{Results and Discussion}

\subsection{Effect of $\mathrm{pH}$}

The $\mathrm{pH}$ of the medium changes during the electrocoagulation process, as observed by many investigators such as [22] [23], so $\mathrm{pH}$ is a significant operating parameter influencing the performance of electrocoagulation influencing the performance of electrocoagulation process [17] [24] [25] [26] [27] [28]. Generally, this change depends on the type of electrode material dye effluent Hence, for examination the effect of initial $\mathrm{pH}$ of solution on the performance of process, the samples were adjusted to the desired value $(3,5,7,10,12)$ for each experiment by adding either sodium hydroxide or dilute sulfuric acid. As shown in Figure 3(a) and Figure 3(b), the $\mathrm{pH}$ of the solution changes during the process. The efficiency of removals was low either at low $\mathrm{pH}$ or at high $\mathrm{pH}$ (3 and 12) and On the other hand, the experimental results showed that when $\mathrm{pH}$ of the dye solution was between 5 and 10 . The optimal pH was 7 with removals efficiency $(98.1 \%, 62 \%)$, color removal and COD removal efficiency respectively at which higher dye removal efficiency could be reached. Also, $\mathrm{pH} 10$ removal efficiency (97.5\% 54\%) color removal and COD removal efficiency respectively and hence this $\mathrm{pH}$ is approximately $\mathrm{pH}$ of real effluent of reactive dyes fabric as indicated in Table 1. Therefore, adjustment of initial $\mathrm{pH}$ before treatment is not required in this treatment using Aluminum anode. Further increasing the $\mathrm{pH} 12$ resulted in a reduction of dye removal efficiency. This behavior was ascribed to the amphoteric character of aluminum hydroxide which does not precipitate at very low $\mathrm{pH}$ [29]. Furthermore, high $\mathrm{pH}$ leads to the formation of $\mathrm{Al}(\mathrm{OH})_{4}^{-}$, which is soluble and useless for adsorption of dye [30] [31]. 


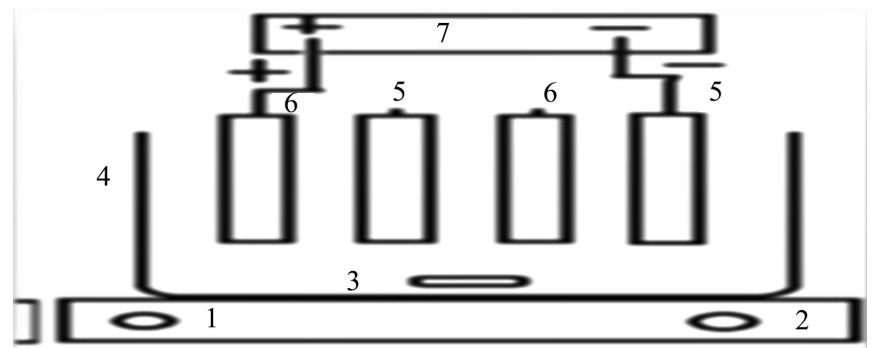

Figure 2. Temperature controllers, 3-Magntic stirrer, 4-EC cell, 5-cathod, 6-Anod, 7-Power supply.

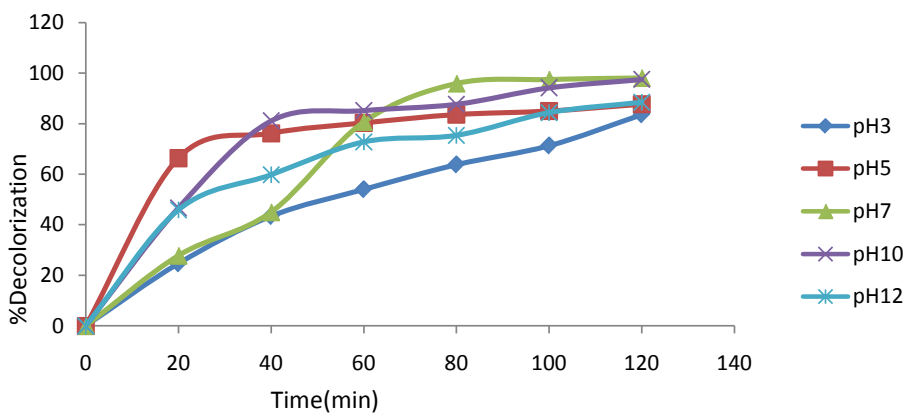

(a)

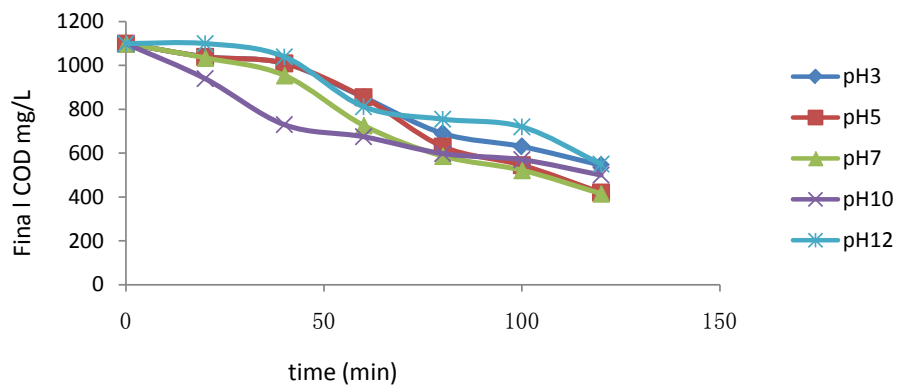

(b)

Figure 3. (a). Effect of initial $\mathrm{pH}$ on the decolorization efficiency (electrical current $=750 \mathrm{~mA}, 1 \mathrm{~cm}$ distance between anodes. (b). Effect of initial $\mathrm{pH}$ on COD efficiency (electrical current $=750 \mathrm{~mA}, 1 \mathrm{~cm}$ distance between anodes.

\subsection{Effect of Electrical Current}

Electrical current is of high significance within all electrocoagulation/flotation processes affecting the reaction rate through the determination of coagulant dosage and bubble generation rates, bubble size, floc growth, collisions among particles and thereby, influencing the ECF efficiency [32]. According to Faraday's law, dissolution of electrode is related to the total charge passed which implies that the amount of adsorbent produced in the electrochemical reactor would be proportional to the electrical current [33]. In addition, electrical current is the prime factor determining the separation mechanism [34]. Thus, in this study, the impact of electrical current on Reactive dye color removals from aqueous synthetics has been examined. As expected, it was observed that at a constant reaction time, the color removal efficiency increased significantly by the increas- 
es of electrical current and that was agree with [11]. An electrical current varying within 300 - $900 \mathrm{~mA}$ was investigated and the results are depicted in Figure 4(a) and Figure 4(b). As it is demonstrated, decolorization Efficiency increased by rising the electrical current reaching to the maximum at $900 \mathrm{~mA}$. This is ascribed to the fact that at higher electrical current, more oxidation occurs within the anodes followed by higher coagulation and flocculation. Moreover, increasing electrical current brings about greater bubble density having smaller size, which effectively promotes pollutant removal by electroflotation [35] [36]. It was observed that the process significantly shown the effect of electrical current in 20 min reaction time as the color of the wastewater undergoes individual decreases by increasing the electrical current. In the present work, the highest decolorization efficiency after $120 \mathrm{~min}$ reaction time was obtained, $750 \mathrm{~mA}$ was selected because it produced relatively high efficiency along with being less energy consuming and more economical.

\subsection{Effect of Electrical Current on Kinetic Evaluation}

Figure 5 (a) presents the linear plot of $\ln C / C_{0}$ versus time and demonstrates that organic matter degradation as a function of the electrical current follows a first order reaction and that the COD removal rate is directly proportional to the applied electrical current. The linear plot of $1 / \mathrm{C}_{0}$ versus time is also illustrated in Figure 5(b). Likewise, demonstrate that the reaction kinetic is more likely to

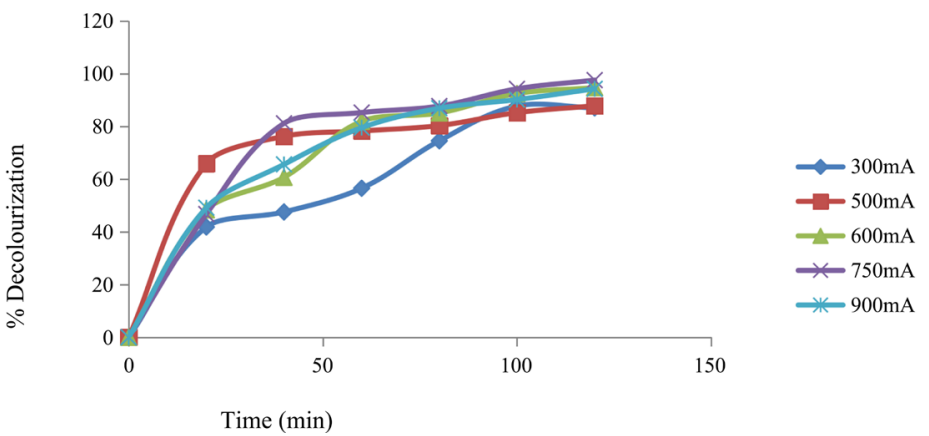

(a)

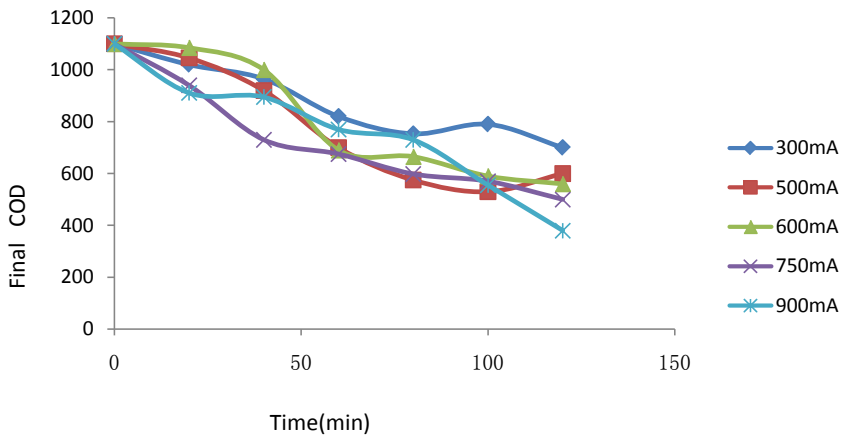

(b)

Figure 4. (a) Effect of electrical current on decolorization $(\mathrm{pH}=$ 10), $1 \mathrm{~cm}$ distance between anodes. (b) Effect of electrical current on $\mathrm{COD}(\mathrm{pH}=10), 1 \mathrm{~cm}$ distance between anodes. 


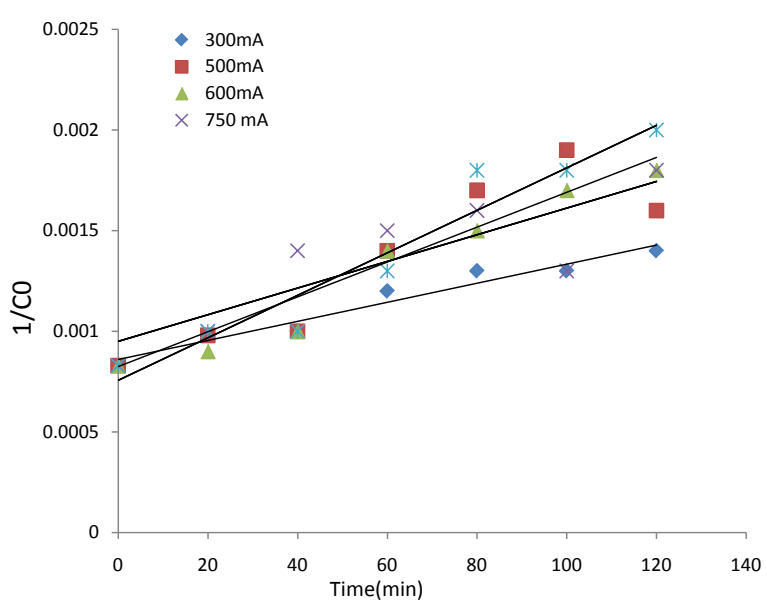

(a)

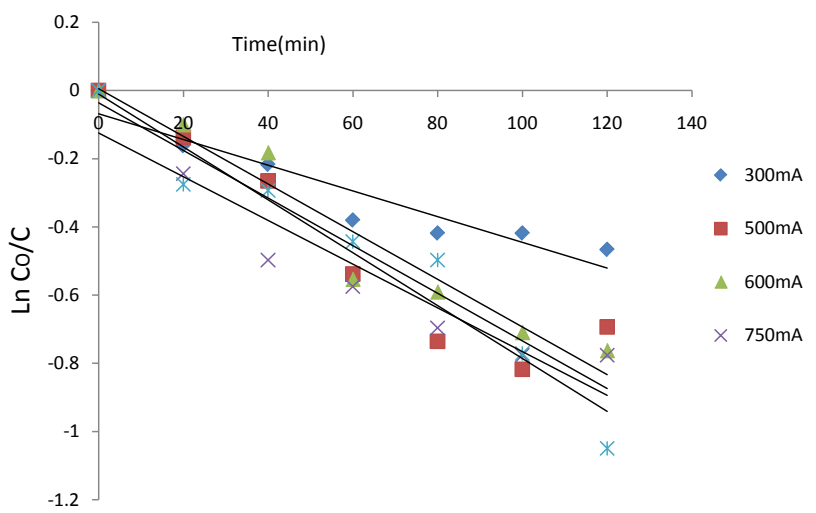

(b)

Figure 5. (a) Effect of electrical current on organic matters removal kinetics. (b). Effect of electrical current on organic matters removal kinetics.

follow the first order. The first order kinetic equation is as follows [37]. $\ln C / C_{0}=$ $-\mathrm{kt}$ where $\mathrm{C}_{0}$ is the initial concentration of organic matters, $\mathrm{C}$ is the remained organic matters after the reaction, $\mathrm{k}$ is the rate constant and $\mathrm{t}$ is the reaction time.

\subsection{Energy Consumption}

Energy consumption is a fundamental factor in all electrochemical processes including ECF being associated with operating cost of the process [38] [39], Electrical current relates with the electrical energy consumption. In the current work, electrical energy consumption per cubic meter of the wastewater undergoing ECF process was calculated through the following equation where $\mathrm{V}, \mathrm{I}$ and $\mathrm{t}$ stand for average voltage of the ECF system (V), electrical current intensity (A) and reaction time (h), there was no considerable difference between $750 \mathrm{~mA}$ and $900 \mathrm{~mA}$ in color removal efficiency. Hence, $750 \mathrm{~mA}$ is economically more feasible owing to its low electrical energy consumption.

$$
\mathrm{Ec}\left(\mathrm{kWh} / \mathrm{m}^{3}\right)=\frac{V \times I \times t}{\mathrm{~m}^{3} \text { wastewater } \times 1000}
$$




$$
\operatorname{Ec}\left(\mathrm{kWh} / \mathrm{m}^{3}\right)=\frac{2 \times 0.75 \times 2}{0.5 \times 0.001 \times 1000}=6 \mathrm{kWh} / \mathrm{m}^{3}
$$

\section{Conclusions}

This study investigated an Electro-Coagulation treatment method for treatment textile Reactive dye wastewater from Textile Mill using Aluminum anode and cathode. The removal efficiency depends on release of electrons from the electrodes. This can be done by increasing the electrical current, where the amount of ions generated can be increased, which leads to higher efficiency. Using various operational variables such as electrocoagulation time, electrical current and $\mathrm{pH}$ were investigated. The result showed that $98.5 \%$ color removal efficiency was achieved at $\mathrm{pH}=10$ and applied current of $750 \mathrm{~mA} .54 \%-65 \%$ COD removal efficiency was achieved with $750 \mathrm{~mA}, 900 \mathrm{~mA}$ respectively with amount of electrical energy Consumption $=6 \mathrm{kWh} / \mathrm{m}^{3}$ without adding any chemicals to the real effluent. Finally, according to findings of this study, it can be concluded that electrocoagulation process can obtain the highest favorable color removal which can make a recycle for waste water, but in case of COD removal, the author recommends adding a help method to complete treatment which agrees with restricted environment.

\section{Conflicts of Interest}

The author declares no conflicts of interest regarding the publication of this paper.

\section{References}

[1] Ballaa, W., Essadki, A.H., Gourich, B., Dassaa, A. and Chenik, H. (2010) Electrocoagulation/Electroflotation of Reactive, Disperse and Mixture Dyes in an External-Loop Airlift Reactor. Journal of Hazardous Materials, 184, 710-716. https://doi.org/10.1016/j.jhazmat.2010.08.097

[2] El-Ashtoukhy, E.S.Z. and Amin, N.K. (2010) Removal of Acid Green Dye 5 from Wastewater by Anodic Oxidation and Electrocoagulation-A Comparative Study. Journal of Hazardous Materials, 79, 113-119. https://doi.org/10.1016/j.jhazmat.2010.02.066

[3] Mahajan, R., Khandegar, V. and Saroha, A.K. (2013) Treatment of Hospital Operation Theatre Effluent by Electrocoagulation. International Journal of Computer and Electrical Engineering, 4, 104-107.

[4] Naraghi, B., Baneshi, M.M., Amiri, R., Dorost, A. and Biglari, H. (2018) Removal of Reactive Black 5 Dye from Aqueous Solutions by Coupled Electrocoagulation and Bio-Adsorbent Process. Electronic Physician, 10, 7086-7094. https://doi.org/10.19082/7086

[5] Mahammedrafi, P. (2018) An Experimental Study of Electrocoagulation Process Applied for Influence of Fluoride Ions on Hardness Removal. International Journal of Engineering Research and Application, 8, 33-38.

[6] Majumder, S. and Rida, U. (2017) Removal of COD from Textile Mill Wastewater by Electro-Coagulation Process Using SS/Al as Composite Hydrogel Electrode. Inter- 
national Journal of Innovative Research in Science, Engineering and Technology, 6, 17242-17250.

[7] Osman, A.T., Elamin, M.R. and Almalki, M.H. (2017) Treatment of Tannery Wastewater with Nano-Electrocoagulation Process. Journal of Environmental \& Analytical Toxicology, 7, 508. https://doi.org/10.4172/2161-0525.1000508

[8] Zazouli1, M.A., Ahmadi, M. and Charati, J.Y. (2017) Pretreatment of Paper Recycling Plant Wastewater by Electrocoagulation Using Aluminum and Iron Electrodes. Journal of Materials and Environmental Sciences, 8, 2140-2146.

[9] Bejjany, B., Lekhlif, B., Eddaqaq, F., Dani, A., Mellouk, H. and Digua, K. (2017) Treatment of the Surface Water by Electrocoagulation-Electroflotation Process in Internal Loop Airlift Reactor: Conductivity Effect on Turbidity Removal and Energy Consumption. Journal of Materials and Environmental Sciences, 8, 2757-2768.

[10] Prieto-García1, F., Callejas-Hernández, J., Prieto-Méndez, J. and Marmolejo- Santillán, Y. (2017) Electrocoagulation of Whey Acids: Anode and Cathode Materials, Electroactive Area and Polarization Curves. Journal of Electrochemical Science and Engineering, 7, 89-101. https://doi.org/10.5599/jese.381

[11] Sajjadi, S.A., Pakfetrat, A. and Irani, M. (2017) Removal of Remazol Black B Dye by Electrocoagulation Process Coupled with Bentonite as an Aid Coagulant and Natural Adsorbent. Iranian Journal of Health, Safety \& Environment, 5, 1058-1065.

[12] Nwabanne, J.T. and Obi, C.C. (2017) Abattoir Wastewater Treatment by Electrocoagulation Using Iron Electrodes. Der Chemica Sinica, 8, 254-260.

[13] Eyvaz, M., Kirlaroglu, M., Selami Aktas, T. and Yuksel, E. (2009) The Effects of Alternating Current Electrocoagulation on Dye Removal from Aqueous Solutions. Chemical Engineering Journal, 153, 16-22. https://doi.org/10.1016/j.cej.2009.05.028

[14] Solanki, M., Sundaramurthy, S., Das, S.N. and Shukla, K. (2013) Treatment of Real Textile Wastewater Using Coagulation Technology. International Journal of ChemTech Research, 5, 610-615.

[15] Mollah, M.Y.A., Morkovsky, P., Gomes, J.A.G., Kesmez, M., Parga, J. and Cocke, D.L. (2004) Fundamentals, Present and Future Perspectives of Electrocoagulation. Journal of Hazardous Materials, 114, 199-210. https://doi.org/10.1016/j.jhazmat.2004.08.009

[16] Kobya, M., Can, O.T., Bayramoglu, M. and Sozbir, M. (2004) Operating Cost Analysis of Electrocoagulation of Textile Dye Wastewater. Separation and Purification Technology, 37, 117-125. https://doi.org/10.1016/j.seppur.2003.09.002

[17] Mollah, M.Y.A., et al. (2004) Treatment of Orange II Azo-Dye by Electrocoagulation (EC) Technique in a Continuous Flow Cell Using Sacrificial Iron Electrodes. Journal of Hazardous Materials, 109, 165-171.

[18] Santhosh, P., RevathI, D. and Saravanan, K. (2015) Treatment of Sullage Wastewater by Electrocoagulation Using Stainless Steel Electrodes. International Journal of Chemical Sciences, 13, 1173-1186.

[19] APHA (2005) Standard Methods for the Examination of Water and Wastewater. 21st Edition, American Public Health Association/American Water Works Association/Water Environment Federation, Washington DC.

[20] Ghanbari, F., Moradi, M., Eslami, A. and Emamjomeh, M.M. (2014) Electrocoagulation/Flotation of Textile Wastewater with Simultaneous Application of Aluminum and Iron as Anode. Environmental Processes, 1, 447-457. https://doi.org/10.1007/s40710-014-0029-3

[21] Kobya, M., Ulu, F., Gebologlu, U., Demirbas, E. and Oncel, M.S. (2011) Treatment 
of Potable Water Containing Low Concentration of Arsenic with Electrocoagulation: Different Connection Modes and Fe-Al Electrodes. Separation and Purification Technology, 77, 283-293.

https://doi.org/10.1016/j.seppur.2010.12.018

[22] Chen, X., Chen, G. and Yue, P.L. (2000) Electrocoagulation and Electroflotation of Restaurant Wastewater. Journal of Environmental Engineering, 126, 858-863. https://doi.org/10.1061/(ASCE)0733-9372(2000)126:9(858)

[23] Vik, E.A., Carlos, D.A., Eikum, A.S. and Gjessing, E.T. (1984) Electrocoagulation of Potable Water. Water Research, 18, 1355-1360. https://doi.org/10.1016/0043-1354(84)90003-4

[24] Chen, G. (2004) Electrochemical Technologies in Wastewater Treatment. Separation and Purification Technology, 38, 11-41. https://doi.org/10.1016/j.seppur.2003.10.006

[25] Kobya, M., Can, O.T. and Bayramoglu, M. (2003) Treatment of Textile Wastewaters by Electrocoagulation Using Iron and Aluminum Electrodes. Journal of Hazardous Materials, 100, 163-178.

[26] Lin, S.H. and Chen, M.L. (1997) Treatment of Textile Wastewater by Chemical Methods for Reuse. Water Research, 31, 868-876. https://doi.org/10.1016/S0043-1354(96)00318-1

[27] Chen, G., Chen, X. and Yue, P.L. (2000) Electrocoagulation and Electroflotation of Restaurant Wastewater. Journal of Environmental Engineering, 126, 858-863. https://doi.org/10.1061/(ASCE)0733-9372(2000)126:9(858)

[28] Do, J.-S. and Chen, M.-L. Decolorization of Dye-Containing Solutions by Electrocoagulation. Journal of Applied Electrochemistry, 24, 785-790.

[29] Adhoum, N. and Monser, L. (2004) Decolourization and Removal of Phenolic Compounds from Olive Mill Wastewater by Electrocoaqulation. Chemical Engineering and Processing: Process Intensification, 43, 1281-1287. https://doi.org/10.1016/j.cep.2003.12.001

[30] Zhu, J., Zhao, H. and Ni, J. (2007) Fluoride Distribution in Electrocoagulation Defluoridation Process. Separation and Purification Technology, 56, 184-191. https://doi.org/10.1016/j.seppur.2007.01.030

[31] Bazrafshan, E., Mahvi, A.H. and Zazouli, M.A. (2014) Textile Wastewater Treatment by Electrocoagulation Process Using Aluminum Electrodes. Iranian Journal of Health Sciences, 2, 16-29.

[32] Modirshahla, N., Behnajady, M.A. and Mohammadi-Aghdam, S. (2008) Investigation of the Effect of Different Electrodes and Their Connections on the Removal Efficiency of 4-Nitrophenol from Aqueous Solution by Electrocoagulation. Journal of Hazardous Materials, 154, 778-786. https://doi.org/10.1016/j.jhazmat.2007.10.120

[33] Kumar, P.R., Chaudhari, S., Khilar, K.C. and Mahajan, S.P. (2004) Removal of Arsenic from Water by Electrocoagulation. Chemosphere, 55, 1245-1252. https://doi.org/10.1016/j.chemosphere.2003.12.025

[34] Holt, P.K., Barton, G.W. and Mitchell, C.A. (2005) The Future for Electrocoagulation as a Localised Water Treatment Technology. Chemosphere, 59, 355-367. https://doi.org/10.1016/j.chemosphere.2004.10.023

[35] Daous, M. and El-Shazly, A. (2012) Enhancing the Performance of a Batch Electrocoagulation Reactor for Chromium Reduction Using Gas Sparging. International Journal of Electrochemical Science, 7, 3513-3526.

[36] Khaled, B., Wided, B., Bechir, H., Elimame, E., Mouna, L. and Zied, T. (2015) In- 
vestigation of Electrocoagulation Reactor Design Parameters Effect on the Removal of Cadmium from Synthetic and Phosphate Industrial Wastewater. Arabian Journal of Chemistry, in press. https://doi.org/10.1016/j.arabjc.2014.12.012

[37] Elmorsi, T.M., Riyad, Y.M., Mohamed, Z.H. and Abd El Bary, H.M. (2010) Decolorization of Mordant Red 73 Azo Dye in Water Using $\mathrm{H}_{2} \mathrm{O}_{2} / \mathrm{UV}$ and Photo-Fenton Treatment. Journal of Hazardous Materials, 174, 352-358.

https://doi.org/10.1016/j.jhazmat.2009.09.057

[38] Emamjomeh, M.M. and Sivakumar, M. (2009) Review of Pollutants Removed by Lectrocoagulation and Electrocoagulation/Flotation Processes. Journal of Environmental Management, 90, 1663-1679.

https://doi.org/10.1016/j.jenvman.2008.12.011

[39] Eslami, A., Moradi, M., Ghanbari, F. and Mehdipour, F. (2013) Decolorization and COD Removal from Real Textile Wastewater by Chemical and Electrochemical Fenton Processes: A Comparative Study. Journal of Environmental Health Science and Engineering, 11, 31. https://doi.org/10.1186/2052-336X-11-31 